\title{
Efektifitas Biofiltrasi Dengan Media Arang Tempurung Kelapa Dan Batu Apung Terhadap Penurunan Kadar COD, Nitrat Dan Amoniak Dalam Air Limbah Domestik
}

\author{
Fivi Elvira Sirajuddin ${ }^{1}$, Muhammad Fadly Saleh ${ }^{2}$ \\ ${ }^{1}$ Teknik Lingkungan, Universitas Teknologi Sulawesi \\ ${ }^{2}$ Teknik Sipil, Universitas Teknologi Sulawesi \\ Surel: ${ }^{1}$ fivie004@gmail.com, ${ }^{2}$ mfadly.uts@gmail.com
}

\section{ABSTRAK}

Penelitian ini dilakukan untuk menentukan komposisi media biofiltrasi yang paling optimal untuk pengolahan air limbah domestik dengan menggunakan 4 reaktor upflow biofilter dengan mengkombinasikan batu apung dan arang tempurung kelapa sebagai media filter. Rasio dari kombinasi media filter tersebut adalah Upflow Anaerobic Filter (UAF) $1=$ $1: 0$, UAF $2=2: 1$, UAF $3=1: 2$, dan UAF 4=1:1 dengan ketebalan media filter secara keseluruhan $60 \mathrm{~cm}$. Waktu pengambilan sampel dilakukan setiap 2 hari selama 16 hari. Pengambilan sampel dilakukan pada keempat reaktor percobaan untuk diujikan masing-masing parameter power of Hydrogen ( $\mathrm{pH})$, Chemical Oxygen Demand (COD), nitrat dan amoniak. Metode analisa yang dilakukan setelah mendapatkan data dari pengujian di laboratorium, yaitu secara deskriptif terkait dengan variasi media filter, dan waktu tinggal air limbah dalam reaktor. Hasil penelitian menunjukkan reaktor yang paling baik pengolahannya dalam menormalkan $\mathrm{pH}$ adalah UAF 1. Sementara komposisi media filter yang paling baik dalam penyisihan COD dan nitrat adalah reaktor UAF 3 dengan hasil penyisihan sebesar $77,78 \%$ dam $87,17 \%$. Penyisihan amoniak terjadi di seluruh reaktor percobaan dengan hasil <-0,05 $\mathrm{mg} / \mathrm{l}$ dinilai cukup baik dan mengindikasikan proses penguraian polutan berjalan dengan baik.
\end{abstract}

\section{Kata kunci}

Filtrasi, Batu apung,

Arang,

COD,

Amoniak

\section{PENDAHULUAN}

Kandungan Chemical Oxygen Demand (COD) yang tinggi dalam air limbah domestik akan menurunkan oksigen terlarut didalam air yang mengakibatkan kondisi perairan tidak mendukung kehidupan bakteri aerobik. Kondisi ini membuat perairan didominasi oleh bakteri anaerobik sehingga meningkatkan produksi amoniak dan sulfide dalam perairan. Amoniak berasal dari kandungan nitrat dalam periran yang tidak terurai dan sulfide berasal dari sulfat yang tidak terurai. Kondisi tersebut memunculkan racun dalam periran sehingga berbahaya bagi kesehatan lingkungan. Pada beberapa instalasi pengolahan air limbah kandungan amoniak selalu menjadi masalah yang tidak terselesaikan akibat tidak sempurnanya penguraian nitrat dalam system pengolahan limbah cair, hal ini menjadi dasar peneliti untuk menjadikan parameter power of Hydrogen $(\mathrm{pH}), \mathrm{COD}$, Nitrat dan Amoniak dalam pengujian hasil pengolahan limbah cair domestik.

Sistem pengolahan limbah cair terbagi atas 2 yaitu secara aerob dan secara anaerob. 
Sistem anaerobik yang diangkat dalam penelitian ini adalah biofiltrasi aliran keatas (upflow anaerobic filter), yaitu suatu unit kontak, di mana air limbah melewati massa padatan biologis yang terkandung di dalam reaktor yang dilengkapi dengan media ${ }^{[1]}$. Sistem pengolahan ini dipilih dengan pertimbangan proses penguraian COD dan nitrat paling besar terjadi dalam sistem pengolahan anaerob. Kandungan amoniak yang minim pada efluen pengolahan menjadi salah satu parameter keberhasilan pengolahan limbah cair.

Keuntungan pengolahan limbah anaerob lainnya adalah mampu mengolah limbah dengan beban organik yang tinggi, tahan terhadap debit yang berfluktuasi, pemeliharaan dan operasional mudah dan murah terkait pemakaian energi, kemampuan menyisihkan COD dan padatan yang cukup tinggi. biaya operasional dan pemeliharaannya yang lebih murah, energi yang diperlukan lebih sedikit dan lumpur dari proses pengolahan lebih sedikit dan kemudian dapat dimanfaatkan untuk menjadi energi terbarukan. Sementara kelemahannya adalah dapat terjadi penyumbatan sehingga membutuhkan konstruksi dan perencanaan yang matang, reduksi nutrien dan patogen yang rendah, membutuhkan pengolahan lanjutan, dan waktu start-up yang lama Selain untuk menumbuhkan lapisan biofilm, proses start up diperlukan untuk adaptasi lumpur untuk mengurangi efek racun dari produksi Amoniak dan sulfida.

Sistem anaerobik yang diangkat dalam penelitian ini adalah biofiltrasi aliran keatas, yaitu suatu unit kontak, di mana air limbah melewati massa padatan biologis yang terkandung di dalam reaktor yang dilengkapi dengan media dengan arah aliran ke atas. Upflow anaerobic filter (UAF) pertama kali diperkenalkan oleh Young dan McCarty pada tahun $1969^{[2]}$.

Parameter desain utama dari filter anaerobik adalah debit selain itu efektifitas biofilter dalam mengolah air limbah sangat dipengaruhi oleh parameter hidraulik media filter yang meliputi luas permukaan spesifik, porositas, kekasaran permukaan, ukuran pori dan bahan media filter ${ }^{[3]}$.

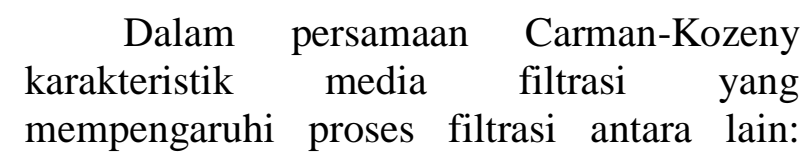
bentuk media, diameter media, porositas, volume rongga media, volume media16. Media filter digunakan untuk mempertahankan padatan dalam reaktor, baik dengan pembentukan biofilm pada permukaan media atau oleh padatan yang tersimpan dalam atau di bawah celah media. Media dirancang untuk menempati sekitar 50 sampai $70 \%$ dari tinggi reaktor ${ }^{[4]}$.

Semakin besar luasan biomassa yang terlekat dalam media filter maka semakin besar kontak yang terjadi dengan bahan organik yang akan diurai, yang pada akhirnya akan meningkatkan efesiensi pengolahan. Sehingga diperlukan media filter dengan luas permukaan yang besar, selain itu hal ini dapat mencegah terjadinya penyumbatan dalam media filter. Sassed an Morel mengatakan untuk kondisi ideal, material disediakan untuk luas permukaan antara 90 hingga $300 \mathrm{~m}^{2}$ untuk mengisi per $\mathrm{m}^{3}$ volume reaktor ${ }^{[5]}$.

Media filter yang digunakan dalam UAF dapat berupa pasir, kerikil, plastik, arang tempurung kelapa, batu apung, karang, dan lain-lain. Pemilihan media filter menjadi salah satu penentu keberhasilan UAF dengan mempertimbangkan luas area kontak dengan air limbah dan porositas yang tinggi. Namun Media filter dengan porositas tinggi belum menjamin keberhasilan dalam biofiltrasi terkait dengan waktu tinggal hidraulik menjadi singkat akibat porositas yang tinggi sehingga kualitas efluen biofiltrasi menurun. Untuk menjawab permasalahan diatas, peneliti akan menggunakan kombinasi media filter yang kemudian disebut dengan dual media dengan media batu apung dan arang tempurung kelapa terkait dengan karakter hidraulis yang dimiliki kedua media tersebut.

Batu apung dapat digunakan sebagai media filter dalam pengolahan air limbah sebagai tempat berkembangbiaknya mikroorganisme dalam sistem pengolahan air limbah9, dengan rongga berlimpah yang membuatnya tergolong dalam material ringan dengan pori yang cukup banyak (volume pori hingga 85\%) dengan densitas sekitar 0,5-1 $\mathrm{kg} / \mathrm{l}$. Porositas yang tinggi dari batu apung 
berbanding lurus dengan rasio yang tinggi antara luas permukaan dan ukuran partikel. Batu apung memiliki pori-pori dengan bentuk yang beragam yang biasanya tidak terhubung satu sama lain. Arang tempurung kelapa bersifat adsorben yang sangat menguntungkan dalam pengolahan limbah cair karena dapat menurunkan konsentrasi polutan dalam cakupan yang luas (Droste dalam beyene dkk, 2014). Adapun susunan media filter dalam reaktor biofiltrasi dengan aliran keatas yaitu media filter dengan porositas rendah diletakkan dilapisan atas dan dibawahnya diletakkan media dengan porositas yang lebih tinggi Media filter akan diaplikasikan dalam reaktor biofiltrasi dengan aliran ke atas atau UAF dimana media filter dengan porositas tinggi akan diletakkan pada bagian bawah lapisan dan media dengan porositas yang lebih rendah akan diletakkan pada lapisan atas. Penggunaan dua media filter hingga 3 lapisan filter dengan kedalaman antara $0,8 \mathrm{~m}$ hingga 1,2 $\mathrm{m}$ dalam UAF.

Tujuan umum dalam penelitian ini adalah untuk menentukan komposisi media biofiltrasi yaitu kombinasi antara batu apung dan arang tempurung kelapa yang paling optimal dalam mengolah air limbah domestik, dengan melihat hasil analisa dari data uji laboratorium untuk parameter $\mathrm{pH}, \mathrm{COD}$, Nitrogen dan Amoniak.

\section{METODE PENELITIAN Alat dan Bahan}

Penelitian ini menggunakan pendekatan kualitatif dengan menggunakan rangkaian alat percobaan skala lapangan sebagai instrument tunggal penelitian. Limbah cair rumah sakit diambil dari bak anerob IPAL RS.Wahidin Makassar sebagai inokulum dalam reaktor percobaan, sedangkan sampel diambil langsung dari rumah tinggal di Sudiang, Kecamatan Biringkanaya Kota Makassar.
Penelitian ini menggunakan alat biofilter dengan aliran keatas sebanyak 4 buah dengan masing-masing diameter 8 inchi dan panjang $90 \mathrm{~cm}$, serta dilengkapi dengan bak ekualisasi untuk mengalirkan air limbah ke masing-masing reaktor. Tabung-tabung biofilter tersebut tersebut dirangkai menjadi satu reaktor (Gambar 1)

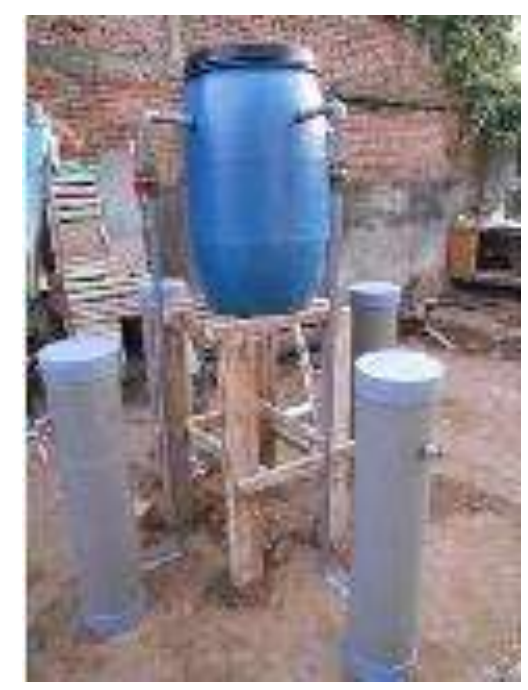

Gambar 1. Foto rangkaian alat percobaan (Sumber: Dokumentasi penelitian, 2019)

Adapun susunan media filter dalam reaktor biofiltrasi dengan aliran keatas yaitu media filter dengan porositas rendah diletakkan dilapisan atas dan dibawahnya diletakkan media dengan porositas yang lebih tinggi Media filter akan diaplikasikan dalam reaktor biofiltrasi dengan aliran ke atas (UAF) dimana media filter dengan porositas tinggi akan diletakkan pada bagian bawah lapisan dan media dengan porositas yang lebih rendah akan diletakkan pada lapisan atas. Penggunaan dua media filter hingga 3 lapisan filter dengan kedalaman antara $0,8 \mathrm{~m}$ hingga 1,2 $\mathrm{m}$ dalam UAF direkomendasikan oleh sperling dan chernicharo ${ }^{[6]}$. 
Gambar potongan memanjang reaktor percobaan biofilter dengan aliran keatas dan alat-alat pelengkap lainnya seperti pada gambar berikut ini.

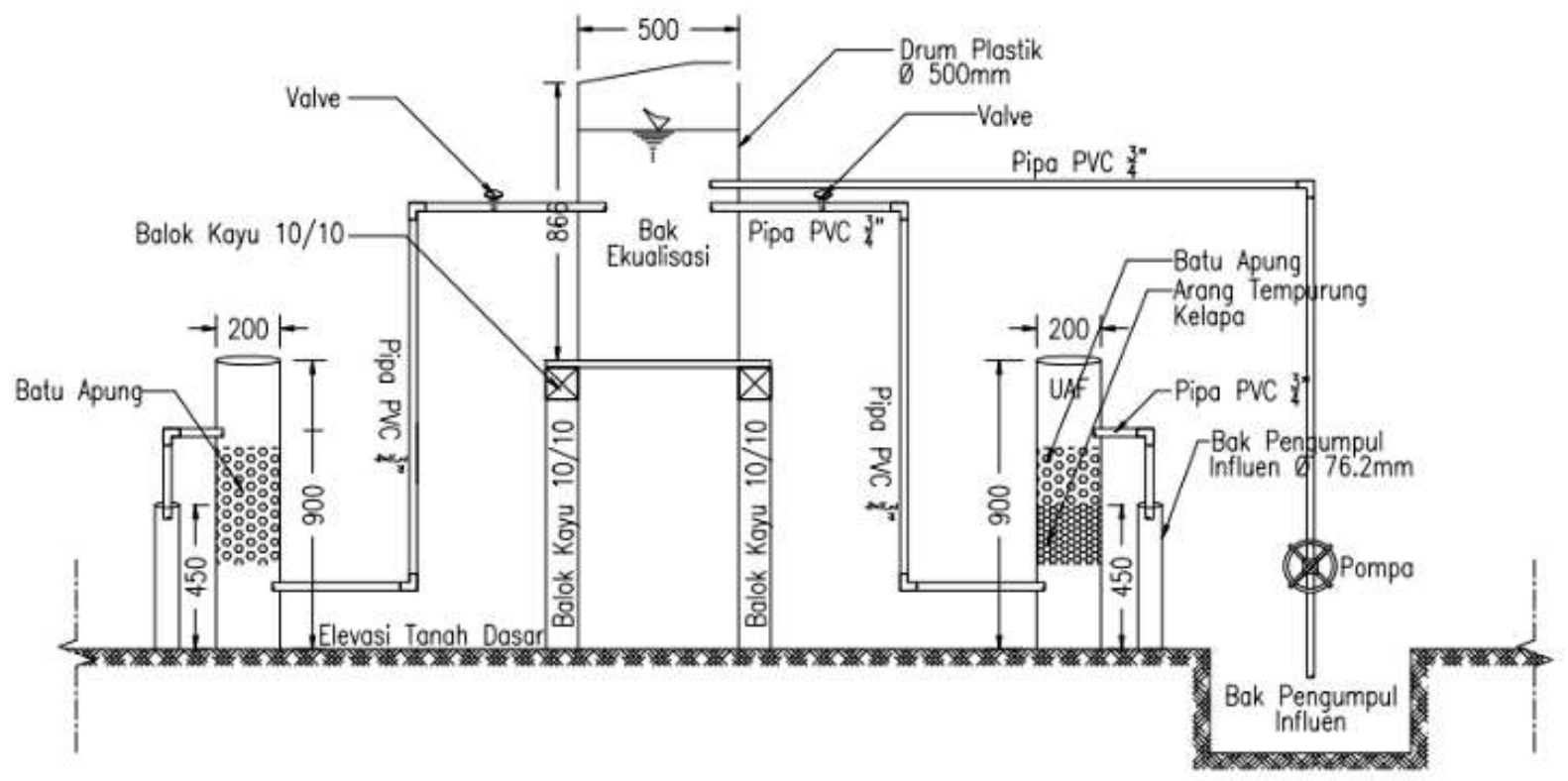

Gambar 2 Rangkaian reaktor percobaan tampak samping Sumber : Fivi Elvira (2019)

Adapun spesifikasi untuk masingmasing reaktor UAF dapat dilihat pada tabel berikut ini.

Tabel 1 Spesifikasi reaktor

\begin{tabular}{|c|c|c|c|c|c|}
\hline \multirow{3}{*}{ Karakteristik } & \multirow{3}{*}{ Unit } & \multicolumn{4}{|c|}{ Nilai } \\
\hline & & UAF & UAF & UAF & UAF \\
\hline & & 1 & 2 & 3 & 4 \\
\hline Mode operasi & & \multicolumn{4}{|c|}{ Kontinyu } \\
\hline Mode aliran & & \multicolumn{4}{|c|}{ Upflow } \\
\hline Kedalaman & $\mathrm{cm}$ & \multicolumn{4}{|c|}{60} \\
\hline $\begin{array}{l}\text { Rasio media } \\
\text { filter* }\end{array}$ & $\%$ & $1: 0$ & $1: 2$ & $2: 1$ & $1: 1$ \\
\hline Total tinggi & $\mathrm{cm}$ & \multicolumn{4}{|c|}{90} \\
\hline Diameter & $\mathrm{cm}$ & \multicolumn{4}{|c|}{20} \\
\hline Volume total & $\mathrm{m}^{3}$ & \multicolumn{4}{|c|}{0,612} \\
\hline
\end{tabular}

Sumber : Fivi Elvira (2015)

Ket: *) Media filter terdiri dari batu apung, arang, tempurung kelapa

\section{Prosedur Penelitian}

Pengumpulan data dilakukan dengan pengambilan sampel untuk kemudian diujikan di Balai Besar Laboratorium Kesehatan Makassar. Sampel yang diambil untuk diujikan adalah sampel air limbah sebelum proses pengolahan dan sampel air limbah pada masing masing akhir pengolahan dari keempat biofilter setiap 2 hari sebanyak 8 kali (16 hari). Variabel bebas dalam penelitian ini adalah pH, COD, Nitrat dan Amoniak, sedangkan variabel tetap adalah variabel yang dijaga tetap sama baik dalam perlakukan maupun kondisinya, yaitu komposisi media filter dan waktu pengambilan sampel.

Pengamatan pada reaktor percobaan dilakukan untuk membandingkan optimalisasi antara media filter terkait dengan efesiensi dalam pengolahan air limbah. Waktu tinggal hidraulik atau hydraulic retention time (HRT) yang disarankan yaitu antara 12 jam hingga 36 jam dengan diameter bahan media filter antara 4-8 $\mathrm{mm}, 8-12 \mathrm{~mm}$ dan $12-18 \mathrm{~mm}^{[7]}$, dalam penelitian ini HRT adalah 48 jam

Pengolahan limbah diawali dengan Inokulasi dengan lumpur anaerobik sebanyak $20 \%$ dari volume operasional reaktor, lumpur anaerobik diambil dari Instalasi Pengolahan Air Limbah domestik. Sampel lumpur anaerobik diambil pada kedalam $50 \mathrm{~cm}$ di bawah permukaan air untuk memastikan bahwa sampel tersebut berasal dari zona bakteri anaerob, bukan dari zona fakultatif.. Air limbah rumah tangga dialirkan secara kontinyu ke masing-masing reaktor UAF. 
Pengambilan sampel air limbah dilakukan selama 16 hari yaitu setiap 48 jam. Pengamatan fisik pada reaktor mengikuti tabel di bawah ini. dengan pengambilan sampel pada limbah cair rumah tangga, pada outlet bak ekualisasi dan pada outlet UAF. Hasil pengamatan dan pengujian laboratorium akan dianalisa dengan melihat grafik dan pendekatan-pendekatan teori untuk mencapai tujuan penelitian yaitu menentukan komposisi media filter yang paling efisien dalam pengolahan air limbah khususnya dalam penyisihan parameter $\mathrm{pH}, \mathrm{COD}$, Nitrat dan Amoniak. Besaran perubahan parameter yang diujikan di sederhanakan ke dalam bentuk efesiensi atau persentase perubahan dalam analisa tersebut. Efesiensi pengolahan yang didapatkan adalah nilai perbandingan antara selisih nilai yang keluar dan masuk dibagi dengan nilain yang keluar dari proses pengolahan. Besarnya efesiensi pengolahan dinyatakan dalam persentase (\%) dengan menggunakan rumus sebagai berikut.

$\mathrm{Ef}_{\text {pengolahan }}=\frac{\mathrm{C}_{\text {in }}-\mathrm{C}_{\mathrm{ef}}}{\mathrm{Cef}} \times 100 \%$
Keterangan :

$\mathrm{Ef}_{\text {pengolahan }}=$ Efesiensi Pengolahan

$\mathrm{C}_{\mathrm{in}}=$ Konsentrasi parameter dalam air limbah yang masuk ke dalam pengolahan

$\mathrm{C}_{\mathrm{ef}}=$ Konsentrasi parameter dalam air limbah hasil pengolahan

\section{HASIL DAN PEMBAHASAN}

Salah satu penyebab utama pencemaran lingkungan di Kota Makassar adalah akibat dari buangan air limbah rumah tangga yang tidak diolah ke badan air dengan kandungan amoniak yang cukup besar dan dapat dirasakan melalui bau tak sedap yang muncul dari perairan ${ }^{[8]}$. Hal tersebut menjadi dasar bagi peneliti untuk menjadikan parameter $\mathrm{pH}$, COD, nitrat dan amoniak sebagai variabel dalam penelitian ini Proses filtrasi dengan aliran ke atas (upflow) dilakukan dengan menggunakan media arang tempurung kelapa dan batu apung dengan rasio yang berbeda disetiap filter. Setelah itu air limbah yang masuk (influen) dan hasi pengolahan (efluen) dari keempat biofilter dibawa ke laboratorium untuk di analisa kandungan kimia airnya. Data hasil pengujian kimia air pada percobaan ditunjukkan Tabel 2.

Tabel 2. Hasil pengujian kimia Air Limbah (influen dan efluen)

\begin{tabular}{|c|c|c|c|c|c|c|c|c|c|c|}
\hline \multirow{2}{*}{ Parameter } & \multirow{2}{*}{ UAF } & Influen & \multicolumn{8}{|c|}{ Efluen } \\
\hline & & 0 & 2 & 4 & 6 & 8 & 10 & 12 & 14 & 16 \\
\hline \multirow[t]{4}{*}{$\mathrm{pH}$} & 1 & 7,8 & 7,6 & 7,32 & 6,9 & 6,91 & 7,02 & 6,9 & 6,95 & 7 \\
\hline & 2 & & 6 & 6 & 6 & 6,1 & 6,2 & 6,5 & 6,7 & 6,9 \\
\hline & 3 & & 6 & 6,81 & 6 & 6,3 & 6,6 & 6,8 & 6,9 & 6,9 \\
\hline & 4 & & 8 & 7,9 & 7,9 & 7,6 & 7,3 & 7 & 7,2 & 7,1 \\
\hline \multirow[t]{4}{*}{ COD } & 1 & 4643,6 & 3071,6 & 2453,2 & 1679 & 1657,9 & 1983,5 & 1999,8 & 2011,67 & 2035,7 \\
\hline & 2 & & 3846,4 & 2657,8 & 1524,7 & 1476,7 & 1374,7 & 1345,6 & 1316,8 & 1289 \\
\hline & 3 & & 3535,8 & 2557,8 & 1589,4 & 1757,6 & 1031,4 & 1265,8 & 1532,8 & 1650,3 \\
\hline & 4 & & 3500,6 & 2587,9 & 1664,4 & 1580,7 & 1498,3 & 1434,5 & 1423 & 1373,8 \\
\hline \multirow[t]{4}{*}{ Nitrat } & 1 & 0,39 & 0,27 & 0,27 & 0,25 & 0,23 & 0,22 & 0,22 & 0,2 & 0,18 \\
\hline & 2 & & 0,34 & 0,41 & 0,53 & 0,42 & 0,38 & 0,35 & 0,27 & 0,24 \\
\hline & 3 & & 0,1 & 0,9 & 0,77 & 0,3 & 0,05 & 0,04 & 0,03 & 0,03 \\
\hline & 4 & & 0,14 & 0,13 & 0,12 & 0,07 & 0,03 & 0,17 & 0,18 & 0,21 \\
\hline \multirow[t]{4}{*}{ Amoniak } & 1 & 0,16 & $<0.05$ & $<0.05$ & $<0.05$ & $<0.05$ & $<0.05$ & $<0.05$ & $<0.05$ & $<0.05$ \\
\hline & 2 & & $<0.05$ & $<0.05$ & $<0.05$ & $<0.05$ & $<0.05$ & $<0.05$ & $<0.05$ & $<0.05$ \\
\hline & 3 & & $<0.05$ & $<0.05$ & $<0.05$ & $<0.05$ & $<0.05$ & $<0.05$ & $<0.05$ & $<0.05$ \\
\hline & 4 & & $<0.05$ & $<0.05$ & $<0.05$ & $<0.05$ & $<0.05$ & $<0.05$ & $<0.05$ & $<0.05$ \\
\hline
\end{tabular}

Hubungan Komposisi Media Filter Dan Waktu Tinggal Air Limbah Dalam UAF Terhadap Derajat Keasaman (pH)
Nilai pH normal untuk air tanah biasanya antara 6 sampai dengan 8,5. Nilai ambang batas $\mathrm{pH}$ untuk air minum sesuai dengan Permenkes No 492/Menkes/Per/IV/ 
2010 yaitu $6,5-8,5^{[9]}$. Air dengan $\mathrm{pH}$ rendah $(<6,5)$ berupa asam, mengandung padatan rendah, dan korosif. Air dengan kondisi seperti ini dapat mengandung besi, dan lainlain. Sedangkan untuk air dengan $\mathrm{pH}$ tinggi $(>8,5)$ berupa basa, yang mempengaruhi rasa air. $\mathrm{pH}$ sebelum pengolahan menunjukkan 7.8 yang berarti air bersifat basa yang diakibatkan oleh kandungan air limbah rumah tangga yang mengandung detergen, cairan pembersih rumah tangga dan penguraian zat zat anorganik lainnya.

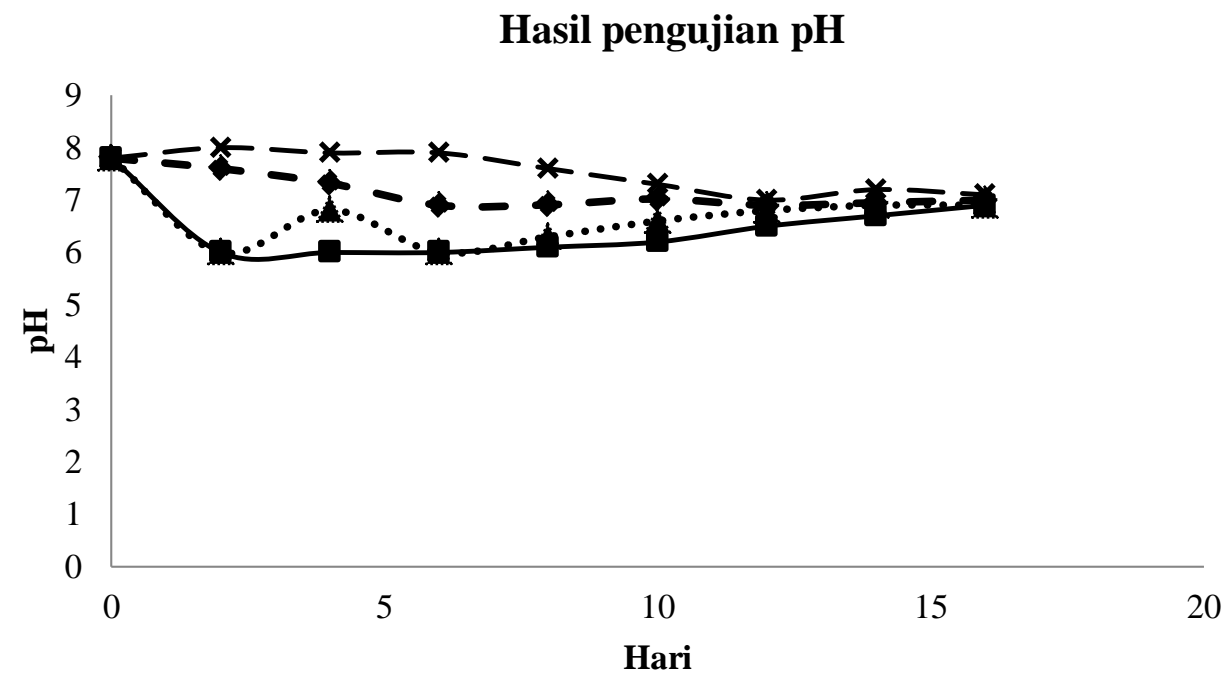

$\leadsto$ UAF $1 \rightarrow$ UAF $2 \cdots \cdot$ UAF $3 \rightarrow x-U A F 4$

Gambar 3. Hubungan komposisi media filter dan waktu tinggal air limbah dalam UAF terhadap $\mathrm{pH}$

Hasil pengolahan dengan keempat reaktor pada percobaan ini dapat dilihat melalui grafik 1. .Setelah dilakukan proses filtrasi dengan aliran keatas, didapatkan hasil terbaik pada media filter batu apung dengan ketebalan $60 \mathrm{~cm}$ (UAF 1) dengan $\mathrm{pH}$ efluen normal yaitu 7 pada hari ke 16 dengan perubahan $\mathrm{pH}$ pada hari sebelumnya yang cenderung stabil mendekati normal. Hal ini sesuai dengan pernyataan bahwa batu apung merupakan salah satu sumber silika yang dapat dipakai dalam menetralkan derajat keasaman air ${ }^{[10]}$.

\section{Hubungan komposisi media filter dan waktu tinggal air limbah dalam UAF terhadap COD \\ COD (Chemical Oxygen Demand) atau} KOK (kebutuhan oksigen kimiawi) adalah jumlah (mg) oksigen yang dibutuhkan untuk mengoksidasikan zat organik dalam 1 liter air menggunakan oksidator kalium dikromat selama 2 jam pada suhu $150^{\circ} \mathrm{C}$. COD menunjukkan senyawa organik yang tidak dapat didegradasi secara biologis ${ }^{[11]}$. Hasil pengolahan dengan keempat reaktor percobaan dapat dilihat pada Gambar 4.

Pada penelitian ini nilai COD sebelum pengolahan adalah 4643,6 mg/l. Setelah dilakukan pengolahan diperoleh hasil terbaik didapatkan pada filter dengan media batu apung $40 \mathrm{~cm}$ dan arang tempurung kelapa 20 cm (UAF 3) di hari kesepuluh yaitu 1031.41 $\mathrm{mg} / \mathrm{l}$ atau dengan efesiensi penyisihan COD sebesar 77,78 persen. Hal ini didukung oleh besarnya pori pori yang dimiliki batu apung sebagai media filter anaerob yang membantu dalam penyisihan parameter COD. Arang batok kelapa mempunyai kemampuan mengurangi konsentrasi surfaktan dengan efesiensi penyisishan COD yang lebih besar dengan proses kontinyu ${ }^{[12]}$. 


\section{COD}

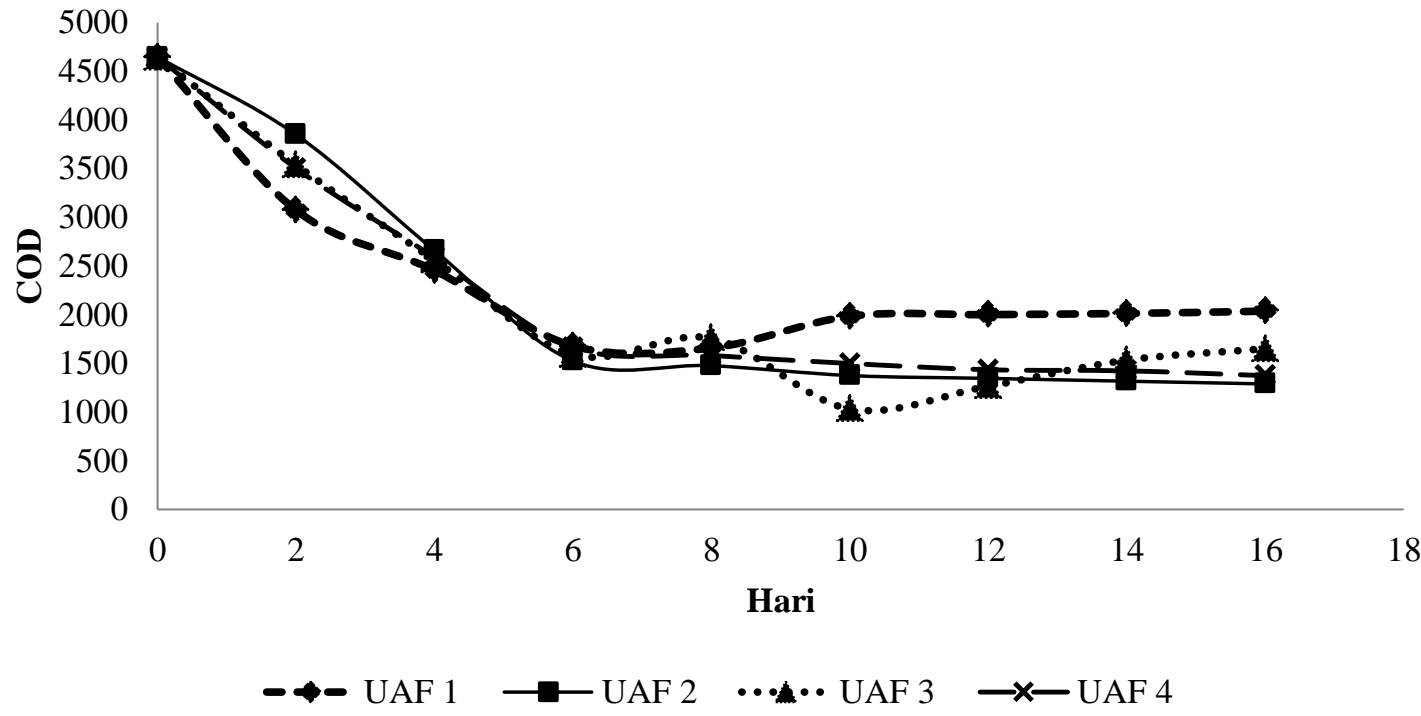

Gambar 4. Hubungan komposisi media filter dan waktu tinggal air limbah dalam UAF terhadap COD

Hubungan komposisi media filter dan waktu tinggal air limbah dalam UAF terhadap Nitrat

Nitrat dalam air limbah adalah hasil proses oksidasi sempurna nitrogen melalui proses nitrifikasi yang melibatkan bakteri nitrosomonas yang mengoksidasi amoniak menjadi nitrit dan bakteri nitrobacter yang mengoksidasi nitrit menjadi nitrat ${ }^{[8]}$. Hasil pengolahan dengan keempat reaktor percobaan dapat dilihat pada Gambar 5.

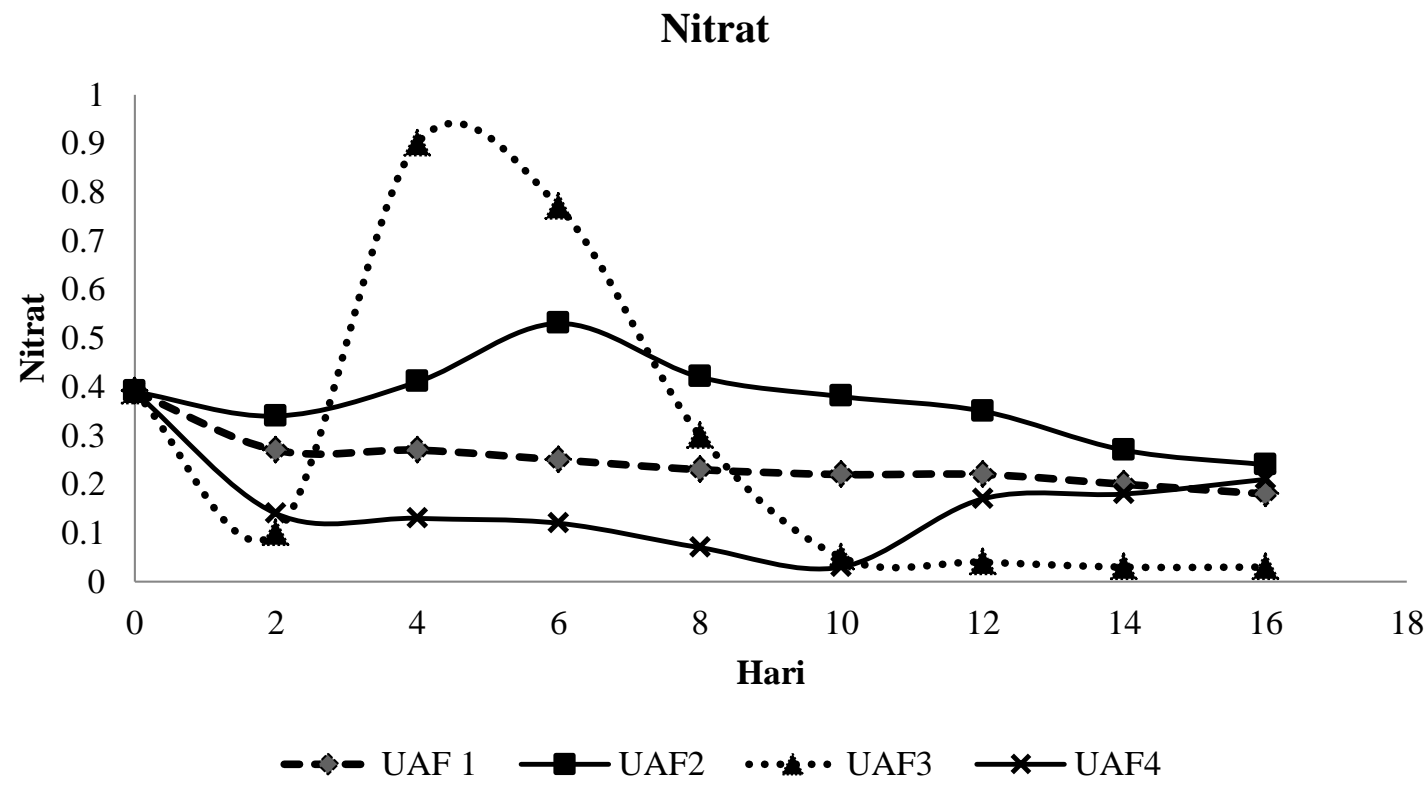

Gambar 5. Hubungan komposisi media filter dan waktu tinggal air limbah dalam UAF terhadap Nitrat

Kandungan nitrat sebelum pengolahan adalah $0,39 \mathrm{mg} / \mathrm{l}$. Setelah dilakukan pengolahan penyisihan terbesar terjadi pada media filter dengan komposisi batu apung setebal $40 \mathrm{~cm}$ dan arang tempurung kelapa 20 $\mathrm{cm}$ (UAF 3) pada hari ke 10 dengan efesiensi penyisihan sebesar $87,17 \%$. 
Hubungan komposisi media filter dan waktu tinggal air limbah dalam UAF terhadap Amoniak.

Amoniak yang terukur di perairan berupa amoniak total $\left(\mathrm{NH}_{3}\right.$ dan $\left.\mathrm{NH}^{4+}\right)$. Untuk mengurangi konsentrasi amoniak yang terkandung dalam buangan air limbah domestik baik segar maupun telah terolah, perlu adanya suatu pengolahan terlebih dahulu atau lebih lanjut sebelum dibuang keperairan/badan air. Hasil pengolahan dengan keempat reaktor percobaan dapat dilihat pada Gambar 6.

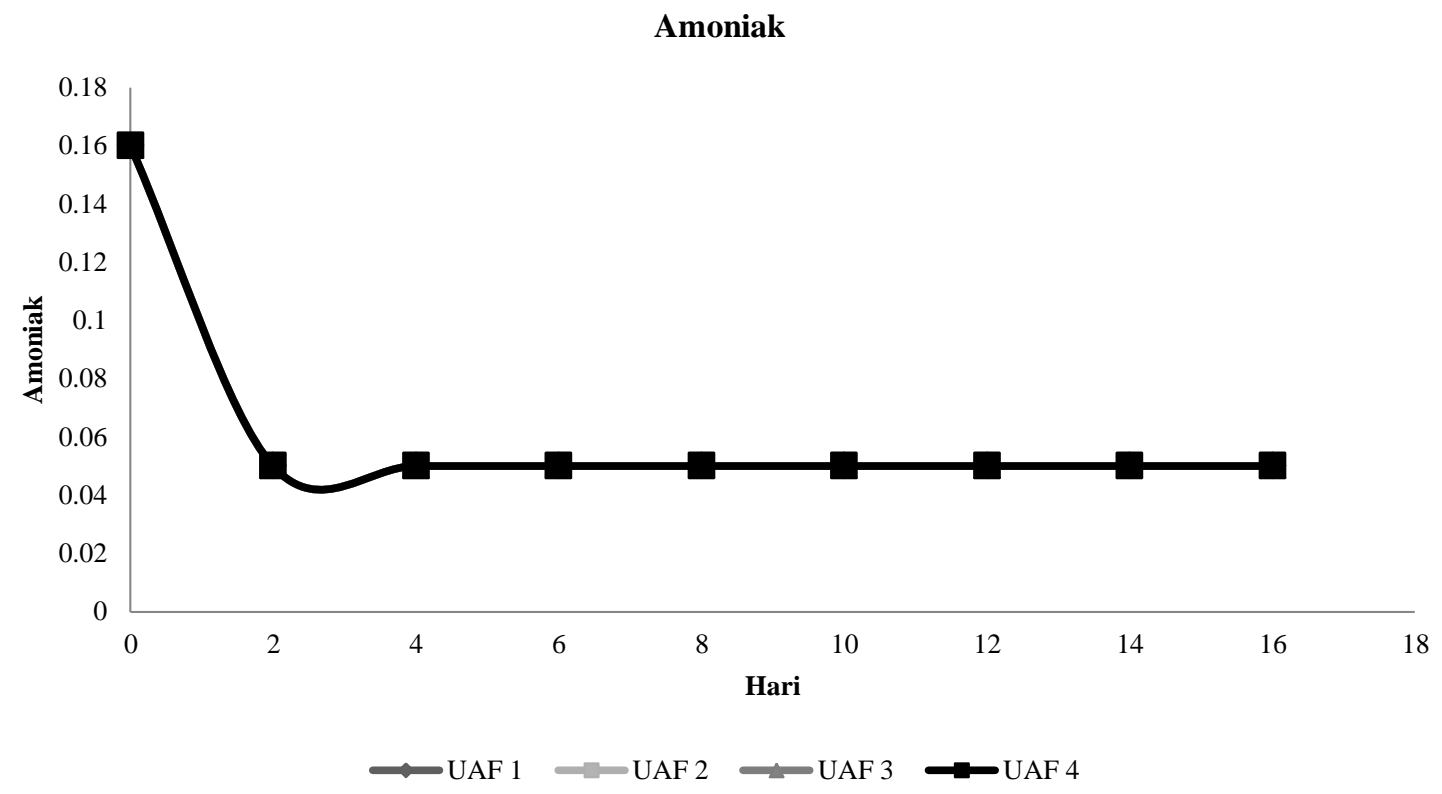

Gambar 6 Hubungan komposisi media filter dan waktu tinggal air limbah dalam UAF terhadap Amoniak

Kandungan amoniak sebelum pengolahan adalah $0,16 \mathrm{mg} / \mathrm{l}$. Setelah dilakukan pengolahan kandungan amoniak di seluruh unit UAF berada di bawah $-0,05 \mathrm{mg} / \mathrm{l}$ atau dengan efesiensi penyisihan $68,75 \%$. Hal ini mengindikasikan proses nitrifikasi yang berjalan baik dalam pengolahan air limbah. Batu apung dan arang tempurung kelapa sebagai media filter, dinilai mampu menurunkan kadar amoniak dalam air limbah domestik

\section{KESIMPULAN}

Reaktor yang paling efektif dalam menormalkan $\mathrm{pH}$ air adalah UAF 1 dengan media filter batu apung dengan ketebalan 60 $\mathrm{cm}$. Reaktor yang paling efektif dalam penyisihan COD dan nitrat adalah UAF 3 (rasio $2: 1$ ) dengan efesiensi penyisihan COD dan Nitrat yaitu $77,78 \%$ dam $87,17 \%$. Penurunan parameter Amoniak terjadi pada keempat reaktor percobaan dengan hasil yang baik dengan hasil pengolahan dengan kandungan amoniak <-0,05 mg/l. Hasil pengolahan masih memerlukan pengolahan lanjutan terkait dengan parameter COD yang masih belum memenuhi standar baku mutu air limbah domestik untuk di buang ke lingkungan ${ }^{[9]}$.

\section{SARAN}

Hasil pengolahan dengan aliran ke atas dengan menggunakan media filter batu apung dan tempurung kelapa dinilai cukup efektif namun masih memerlukan pengolahan lanjutan terkait dengan penyisihan untuk parameter COD yang masih belum memenuhi standar baku mutu air limbah domestik untuk di buang ke lingkungan ${ }^{[9]}$. Penelitian ini juga perlu dilanjutkan dengan menganalisa waktu penyumbatan yang terjadi sebagai salah satu parameter efektifitas biofiltrasi. 


\section{UCAPAN TERIMA KASIH}

Terima kasih kepada Kementerian Riset dan Teknologi dan Pendidikan Tinggi sebagai sponsor pendanaan utama melalui kegiatan Program Penelitian dan Pengabdian Kepada Masyarakat Melalui Simlitabmas Tahun 2018, juga kepada semua pihak yang telah memberikan tenaga dalam merangkai alat dalam penelitian ini.

\section{REFERENSI}

[1] Hidayat, S. S. N., 2012, Horizontal Biofilter System in Tapioca Starch Wastewater Treatment: The Influence of Filter Media on the ffluent Quality. Agroindustrial Journal Vol 1 Issue 1.

[2] F.P. Vand der Zee, C. F., 2015, M. E. Ersahin Celebrating 40 years anaerobic sludge bed reaktors for industrial wastewater treatment, Reviews, Environmental Science and Bio/Technology.

[3] Priyanka, A., 2012, Perancangan Instalasi Pengolahan Air Limbah Pertamina Maritime Training Centre (Studi Perbandingan dengan Instalasi Pengolahan Air Limbah Gedung Pertamina Learning Centre, Fakultas Teknik, Program Studi Teknik Lingkungan, Universitas Indonesia.

[4] Kavitha, K., 2009, Feasibility Study of Upflow Anaerobic Filter for Pretreatment of Municipal Wastewater, Thesis, Singapore, Department of Civil Engineering.

[5] Ulbrich, 2015, Technical Feasibility of decentralised Greywater Treatment Units to improve Sanitation in peri-urban Areas of Ulaanbaatar Mongolia, Thesis, University of Science and Technology Centre for Sustainable Environmental Sanitation Beijing.

[6] Daniel F. ias, T. P.-N., 2014, Overall Performance Evaluation Of Shallow Maturasion Ponds In Series Treating UASB Reaktor Efluen: Ten Years Of Intensive Monitoring Of A System In Brazil, Ecological Journal, 71, 206-214.
[7] Affam, A. C., 2013, Operational Performance Of Vertical Upflow Roughing Filter For Pre-Treatment Of Leachate Using Limestone Filter Media. Journal of Urban and Environmental Engineering.

[8] Moersidik, R. N., 2015, Penurunan kadar Amonia dan Nitrat pada Air Limbah Tambak Udang Menggunakan Fotobioreaktor (FBR) dengan Menumbuhkan Spirulina sp. Depok: Program Studi Teknik Lingkungan, Departemen Teknik Sipil, Fakultas Teknik, Universitas Indonesia.

[9] Kementerian Kesehatan Republik Indonesia, 2017, Peraturan Menteri Kesehatan republik Indonesia Nomor 32 tahun 2017 Tentang Standar Baku Mutu Kesehatan Lingkungan dan Persyaratan Kesehatan Air untuk Keperluan Higene Sanitasi, Kolam renang, Solus per Aqua dan Pemandian Umum, Jakarta, Kementrerian Kesehatan Republik Indonesia.

[10] Febri Melta Mahadilla, A. P., 2013, Pemanfaatan Batu Apung sebagai Sumber Silika Dalam Pembuatan Zeolit Sintetis, Jurnal Fisika Unand, 2 (4).

[11] Asih Kurniasih Lumaela, B. W., 2012, Pemodelan Chemical Oxygen Demand (COD) Sungai di Surabaya Dengan Metode Mixed Geographically Weighted Regression, Jurnal Sains dan Seni POMITS, 2 (1).

[12]Razif, A. H., 2011, Penurunan Konsentrasi Surfaktan alam Limbah cair Laundry dengan Adsorpsi Menggunakan Arang Batok Kelapa (Coconut Shells) Komersil, Digilib UTS. 